OPEN ACCESS

Edited by:

Daniel Paul Costa,

University of California, Santa Cruz,

United States

Reviewed by:

Stephen J. Trumble,

Baylor University, United States

Cathy Debier,

Catholic University of Louvain,

Belgium

${ }^{*}$ Correspondence:

Chadwick V. Jay cjay@usgs.gov

Specialty section:

This article was submitted to

Marine Megafauna,

a section of the journal

Frontiers in Marine Science

Received: 05 September 2020 Accepted: 08 January 2021

Published: 27 January 2021

Citation:

Jay CV, Iverson SJ and Fischbach AS (2021) Variability of Lipids and Fatty Acids in Pacific

Walrus Blubber.

Front. Mar. Sci. 8:603065. doi: 10.3389/fmars.2021.603065

\section{Variability of Lipids and Fatty Acids in Pacific Walrus Blubber}

\author{
Chadwick V. Jay ${ }^{1 *}$, Sara J. Iverson ${ }^{2}$ and Anthony S. Fischbach ${ }^{1}$ \\ ${ }^{1}$ U.S. Geological Survey, Anchorage, AK, United States, ${ }^{2}$ Department of Biology, Dalhousie University, Halifax, NS, Canada
}

The variability of lipid content and fatty acid (FA) composition across blubber depth and body sites are important considerations for condition and diet studies of marine mammals. We investigated lipid and FA variability among inner and outer blubber layers, three body sites, four study years, and lactation status of adult female Pacific walruses (Odobenus rosmarus divergens) using blubber samples collected from subsistenceharvested walruses in spring 2007-2010. Percent lipid content did not differ between the inner and outer blubber layers at the rump, flank, or sternum of walruses. Although FA composition differed between the inner and outer blubber layers, the difference was consistent across body sites, and differences between layers within individual FAs were small $(<2 \%)$. Lipid content at the sternum of lactating females was $6 \%$ higher than non-lactating females, consistent with known variation in body condition among these reproductive classes. Across study years, lipid content varied $18 \%$ and individual FAs varied $6 \%$, likely reflecting population-level interannual variability in energy budgets and small differences in diet among years. Consistency in blubber lipid content across blubber depth and body sites and detectable variation in blubber lipid content among reproductive classes and years suggests the potential for lipid content to be a useful indicator of walrus body condition. In addition to information on condition, FA composition of blubber samples could potentially provide insights into changes in walrus diet that may be expected to occur from changes in their access to prey resources resulting from continued sea ice loss.

Keywords: walrus, blubber, lipid, fatty acid, lactation, condition

\section{INTRODUCTION}

Changes in sea ice habitat and increased human activities in the Arctic are affecting the distribution of ice-associated marine mammals (Laidre et al., 2015). Understanding how changes in animal behavior are linked to regulating population abundance is important so that effective regulations and policies can be established to mediate detrimental effects on Arctic marine mammals. Conceptual models to forecast and predict the response of marine mammal populations to changing environments and human-induced stressors share a common pathway-stressors influence activity budgets or physiological status and thus an animal's energy stores, which affect outcomes of reproduction and survival of young (National Research Council, 2005; New et al., 2014; King et al., 2015; Udevitz et al., 2017; Farmer et al., 2018).

The Pacific walrus (Odobenus rosmarus divergens) is a key Arctic species that occurs in the Chukchi and Bering Seas, feeding primarily on benthic invertebrates inhabiting the seafloor of the 
shallow continental shelves (Fay, 1982; Sheffield and Grebmeier, 2009; Sonsthagen et al., 2020). Sea ice provides walruses a place to rest between foraging bouts, molt, give birth and nurse young, and an offshore refuge from disturbances and predators on shore (Fay, 1982). Ice algae is an important contributor of organic carbon to benthic organisms (Grebmeier, 2012; North et al., 2014; Schollmeier et al., 2017) of which many taxa are important prey for walruses (Sheffield and Grebmeier, 2009). Changes in the timing and extent of seasonal sea ice cover in the Chukchi Sea (Wang et al., 2018) has consequences to the production of walrus prey (Grebmeier et al., 2015), and has led walruses to haul out on land more frequently and spend more time in water and less time resting, with probable declines in net energy gain (Jay et al., 2012, 2017; Udevitz et al., 2017).

Condition indices from individual animals are often used to monitor the status of a population or to understand the relationships between environmental conditions and population vital rates. However, empirical data needed to quantify these relationships are difficult to obtain and are usually lacking (Wilder et al., 2016). A variety of condition metrics have been developed and commonly use measures of body fat, or body mass (usually relative to animal structural size) to infer body fat, to serve as a proxy of animal fitness (Stevenson and Woods, 2006; Wilder et al., 2016). The body mass of wild walruses is difficult to measure in the field because of their large size (weight of adult male and female Pacific walruses range up to about 1,700 and $1,140 \mathrm{~kg}$, respectively, Fay, 1985); therefore, identifying more tractable measures of walrus body condition would be useful in studies of population regulation.

Blubber thickness over the sternum (xiphoid process) is a commonly used body condition index of pinnipeds (American Society of Mammalogists, 1967). However, as for many condition indices, the best body site for sampling may vary with season and animal status (i.e., age, sex, reproduction, etc.) (Ryg et al., 1990; Noren et al., 2015). In wild Pacific walruses, measurements of blubber thickness at several body sites from harvested animals were found to vary significantly between male and female adults and pregnant and non-pregnant females among particular body sites (Quakenbush et al., 1999). Noren et al. (2015) calculated blubber mass from ultrasound measures of blubber thickness at multiple body sites from captive females to identify a body measurement site that best predicted body condition (quantified as mass $\times$ length $^{-1}$ ) in non-pregnant adults. Results from the study were consistent with findings by Quakenbush et al. (1999) of a strong correlation between body mass and shoulder blubber thickness, but weak correlation between body mass and sternum blubber thickness in non-pregnant wild walruses. Accordingly, Quakenbush et al. (1999) did not detect a difference in blubber thickness at the sternum between near-term pregnant and adult non-pregnant females even though captive pregnant females have been shown to gain the equivalent of an estimated $23 \%$ of their non-pregnant body mass to support lactation (Noren et al., 2014). As an alternative, it may be possible that percent blubber lipid content would provide a more direct and sensitive index of fat content than blubber thickness. Lipid content of walrus blubber has not been studied, other than lipid content measured from 15 male and female wild Pacific walruses in a study of persistent organic pollutants (Kucklick et al., 2006). Finding detectable differences in percent lipid content in sternum blubber between lactating and non-lactating females would provide some support that lipid content may have the potential to discriminate between reproductive classes and serve as an index of body condition.

Blubber mass of adult female walruses range between 16-24\% of total body mass in wild Atlantic walruses (O. r. rosmarus) (Knutsen and Born, 1994) and 23-33\% of total body mass in captive Pacific walruses (Noren et al., 2015). The number of adipocytes (fat cells) in mammals can be mediated from diet or extreme exercise in early life, but mammals generally establish a set number of adipocytes by post-weaning that remains constant throughout adulthood and fluctuating weight (Young, 1976; Koopman et al., 2002; Castrillon et al., 2017). The size of the adipocyte changes with fat content as lipids are stored and mobilized (Schemmel, 1976) and is related to overall fatness in a range of taxa (Galicia et al., 2020), but little is known of this relationship in pinnipeds and cetaceans (Koopman et al., 2002; Louis et al., 2014).

Lipid storage is affected by the energy acquired from an animal's diet, which is reflected by the fatty acids (FAs) stored in the blubber (Iverson et al., 2004; Budge et al., 2006; Bromaghin et al., 2017). West et al. (1979) examined the FA composition of blubber from the sternum of Pacific walruses harvested in the Bering Sea, however samples sizes were limited to two males and two females. They did not detect differences within and between sexes but observed a difference in FA composition between the inner and outer blubber layer in a sample from one of the males. Skoglund et al. (2010) investigated the FA composition of the inner and out blubber layers of 18 adult male Atlantic walruses and found relatively small differences in FA composition between blubber layers. Budge et al. (2007) examined the FA composition of full depth blubber samples from nine adult female Pacific walruses harvested in spring. They found the proportions of FAs in the walrus blubber to be unique among marine mammals, owing to the dominance of mollusks in the walrus diet. The FA composition in the blubber of walruses resulting from their unique diet is clearly distinctive from seals and whales (Thiemann et al., 2008).

The variability of lipid content and FA composition across blubber depth and body sites are important considerations for condition and diet studies of marine mammals. We used samples of adult female Pacific walruses from Alaska Native subsistence harvests in spring 2007-2010 to primarily test for differences in lipid content and FA composition between inner and outer blubber layers and among body sites, and secondarily, to examine variation in lipid content and FA composition among study years and lactation status.

\section{MATERIALS AND METHODS}

\section{Field}

Blubber samples were collected from harvested adult female walruses during spring (4 April-3 June) subsistence walrus hunts in 2007-2010 from the Alaska Native communities of Gambell and Savoonga located on St. Lawrence Island, Alaska, in the 
northern Bering Sea. In 2007, blubber samples were collected from three body sites (flank, rump, and sternum, Figure 1) from two non-lactating and 15 lactating walruses (except a flank sample was missing from a lactating female). In 2008-2010, blubber samples were collected from only the sternum from 15 non-lactating and 68 lactating walruses (Table 1). Lactation status was determined by the presence or absence of milk from the mammary glands. The attendance of a calf or yearling with the female was not always confirmed in the field and therefore could not be reliably associated with lactation status. Blubber was cut from the animal such that the sample was bounded by muscle and skin to ensure the full depth of the blubber layer was sampled. The blubber sample was sealed in a plastic bag and brought to shore where it was placed in a household freezer. At the end of the sampling season, samples were transported for longerterm storage in a commercial freezer $\left(-20^{\circ} \mathrm{C}\right)$. All samples were subsequently packaged with dry ice and express-shipped to the lab for analysis (Dalhousie University, Nova Scotia). Research and sample collection were conducted in accordance with U.S. Fish and Wildlife Service, Division of Management Authority, permit numbers MA801652-3 through MA801652-6.

\section{Lab}

In the lab, the full depth of blubber samples collected in 2007 was measured to the nearest $\mathrm{mm}$ (depth was not measured from samples collected in 2008-2010). All blubber samples were cut longitudinally to approximately $1 \times 1 \mathrm{~cm}$ in cross section and then cut cross sectionally to separate the sample into two halves (inner and outer layers). Lipids were quantitatively extracted from each inner and outer blubber section in duplicate aliquots using a modified Folch method (Iverson et al., 2001); fat content is expressed as the average of the two duplicates. FAs were converted to FA methyl esters using acidic transesterification and analyzed using temperatureprogrammed gas liquid chromatography as described in Iverson et al. (2002), on a Perkin Elmer Autosystem II Capillary FID gas chromatograph fitted with a $30 \mathrm{~m} \times 0.25 \mathrm{~mm}$ i.d. column coated with $50 \%$ cyanopropyl polysiloxane $(0.25 \mu \mathrm{m}$ film thickness; J\&W DB-23) and linked to a computerized integration system (Turbochrome 4.1 software, PE Nelson). Approximately 73 FAs were identified, and their proportional amounts were quantified in each sample.

\section{Analysis}

We tested for differences in percent lipid and FA composition among blubber layers, body sites, years, and lactation status using ANOVA and MANOVA with general linear models (SAS Institute Inc., Cary, NC, United States). Tests of significance used an alpha level of 0.05 , which was controlled in univariate multiple comparisons using Tukey tests. Marginal means (least squares means, SAS) are reported in cases of multi-way ANOVA. Underlying assumptions of analyses were assessed with a combination of box and normal probability plots, and tests for normality (Shapiro-Wilk test) and homogeneity of variance (Levene's test).

To identify a more practicable subset of major FAs to use in our analyses, we started by considering only the 41 "extended dietary" FAs (Iverson et al., 2004) from the original 73 FAs that were identified in the inner and outer blubber layers at the three body sites of the 17 walruses sampled in 2007 (Table 1). From these 41 FAs, we selected FAs with an average abundance across walruses of $>1 \%$ within any blubber layer and body site combination. This resulted in our selection of 11 FAs, and these major FAs and their original proportional abundances were used in all subsequent FA analyses. Within any given walrus blubber layer and body site combination, the sum of the proportional abundances of the 11 FAs composed $87-92 \%$ of the sum of the 41 extended dietary FAs and $81-86 \%$ of the sum of the original 73 FAs.

\section{RESULTS}

\section{Comparisons Between Blubber Layers and Body Sites Using Samples Collected in 2007}

Lab-measured blubber depth did not differ significantly among body sites $\left[F_{(2}, 47\right)=0.41, P=0.663$; flank: $\bar{x}=3.9 \mathrm{~cm}, S D=1.0$, range 2.3-6.7; rump: $\bar{x}=4.2 \mathrm{~cm}, S D=1.0$, range $2.2-6.2$; sternum: $\bar{x}=4.2 \mathrm{~cm}, S D=1.1$, range $2.0-5.9$ ]. Sample means and deviations at the rump and sternum were similar to blubber depth measured in the field at these same body sites from adult female Pacific walruses harvested during a similar time of year in another study (Quakenbush et al., 1999; rump: $\bar{x}=3.9 \mathrm{~cm}, S D=0.7$, range 2.7-5.4; sternum: $\bar{x}=4.0 \mathrm{~cm}, S D=1.0$, range $2.5-6.8$ ).

Data from lactating females were used to compare lipid content and FA composition between the inner and outer blubber layers among body sites because only two non-lactating walruses were sampled in 2007 (Table 1). Percent lipid (or percent FA) of the inner layer minus percent lipid (or percent FA) of the outer layer (between-layer difference) was the measurement variable (paired-sample, Zar, 1999).

We tested for differences in the between-layer difference of lipid content among body sites (Figure 2) using ANOVA where between-layer difference at each body site was treated as repeated measures within walrus (within-subjects) (Zar, 1999). A flank sample was missing from one of the 15 walruses (Table 1), so the walrus was omitted. Mauchly's test of sphericity, variances of the differences between all combinations of body sites are equal, indicated that the assumption of sphericity had not been violated $\left[\chi^{2}{ }_{(2)}=2.51, P=0.285\right]$. Between-layer difference in lipid content did not differ among body sites $\left[F_{(2,26)}=3.07\right.$, $P=0.064$ ] or differ from zero within body sites (flank: $\bar{x}=-1.2$, $S E=1.8, P=0.511$; rump: $\bar{x}=3.7, S E=1.8, P=0.059$; sternum: $\bar{x}=2.0, S E=2.0, P=0.341)$.

We tested for differences in the composition of the betweenlayer differences of FAs among body sites (Figure 3) using MANOVA where the 11 FAs were the dependent variables and body site was the independent variable. The composition of between-layer differences of FAs did not differ among body sites [Wilks' lambda $(\Lambda)=0.482, P=0.248$ ], suggesting differences in FA composition between blubber layers was consistent across body sites. Although variances differed among FA-body site 

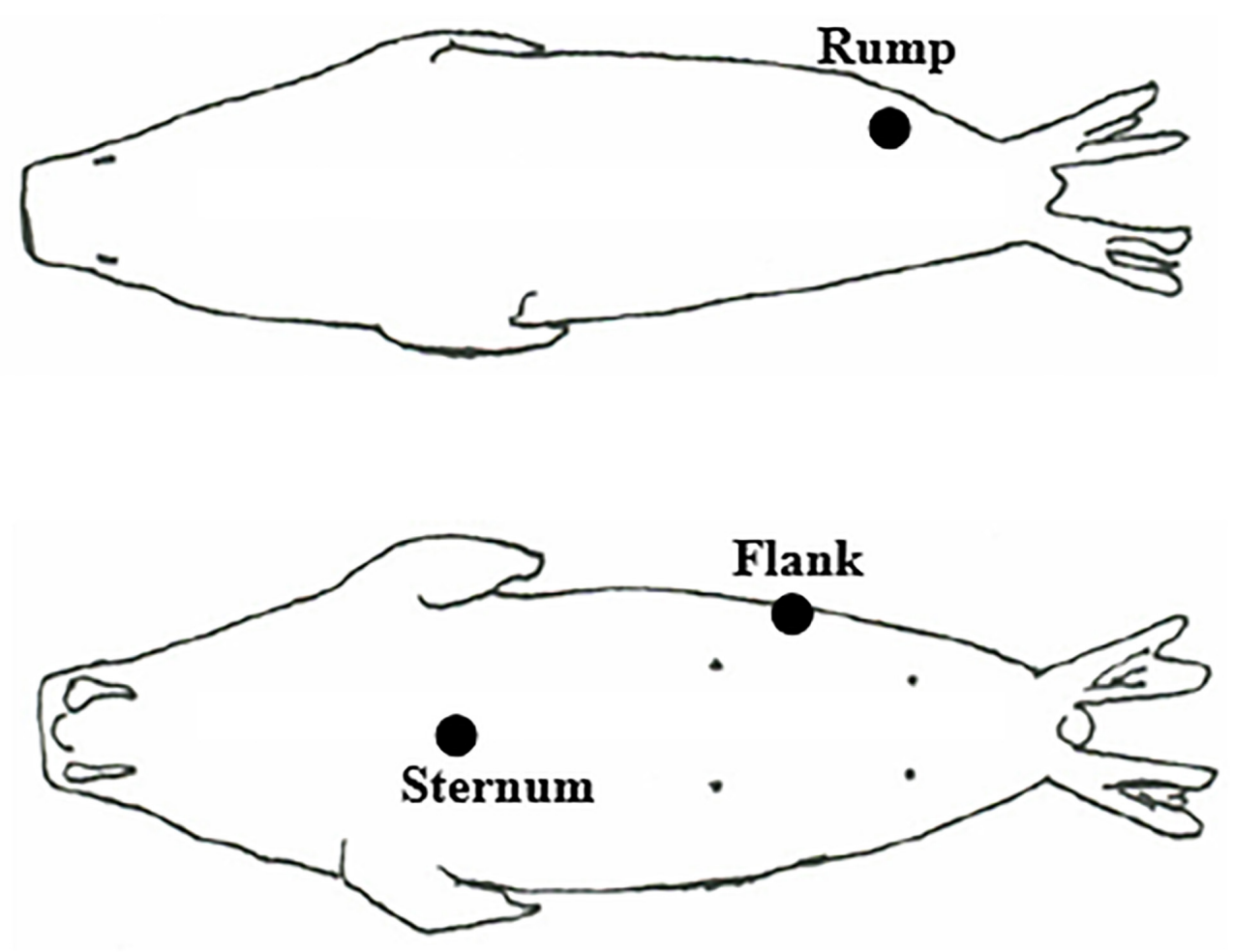

FIGURE 1 | Body sites where blubber samples were collected from adult female Pacific walruses: rump (either side of walrus), flank (either side of walrus, between the rib and hip), and sternum (over xiphoid process).

groups, normality was generally met with a few notable outliers, and since univariate analysis of variance tests of significance are robust to considerable heterogeneity of variances as long as sample sizes are near equal (Zar, 1999), we suggest this result is supported. Within FAs, the between-layer difference (averaged across body sites within walrus) was significant for all FAs $(P \leq 0.006)$ except 22:6n-3 $(P=0.709)$, albeit between-layer differences were small $(\leq 1.6 \%)$ (Figure 4).

\section{Comparisons Between Lactation Status and Years Using Sternum Samples Collected in 2007-2010}

Data from sternum samples collected across all four study years $(n=100)$ were used to compare lipid content and FA

TABLE 1 | Number of adult female Pacific walruses sampled by year.

\begin{tabular}{lccccc}
\hline & $\mathbf{2 0 0 7}$ & $\mathbf{2 0 0 8}$ & $\mathbf{2 0 0 9}$ & $\mathbf{2 0 1 0}$ & Total \\
\hline Non-lactating & 2 & 2 & 5 & 8 & 17 \\
Lactating & 15 & 14 & 10 & 44 & 83 \\
Total & 17 & 16 & 15 & 52 & 100
\end{tabular}

In 2007, samples were collected from the flank, rump, and sternum of each walrus (a flank sample was missing from one lactating female). In 2008-2010, samples were collected from only the sternum of each walrus. All samples provided measures of percent lipid content and proportional abundances of FAs from the inner and outer blubber layers. composition between lactating and non-lactating females and among years. Most samples were collected from lactating females (Table 1) and therefore, because of sample size limitations, we pooled samples across years to make comparisons between lactating and non-lactating females, and separately, we used samples from only lactating females to make comparisons among years.

We tested for differences in percent lipid content using ANOVA with average percent lipid content across blubber layers as our measurement variable because lipid content did not differ between layers (see above). Lipid content at the sternum of lactating females was $6 \%$ higher than non-lactating females (years pooled) $\left[F_{(1}, 98\right)=7.68, P=0.007 ; \bar{x}=78.9, S E=0.8, n=83$; $\bar{x}=73.4, S E=1.8, n=17$, respectively]. Although samples sizes were unequal (Table 1), normality and homogeneity of variance were met. Lipid content of lactating females differed among years $[F(3,79)=22.73, P<0.0001)$, decreasing from a high of $88 \%$ in 2007 to a low of $70 \%$ in 2009, then increasing in 2010 (2007: $\bar{x}=88.1, S E=1.5, n=15 ; 2008: \bar{x}=79.9, S E=1.5, n=14 ; 2009$ : $\bar{x}=69.7, S E=1.8, n=10 ; 2010: \bar{x}=77.5, S E=0.9, n=44)$.

We tested for differences in percent FA composition using MANOVA with the proportional abundance of FAs of the outer blubber layer as our measurement variable because FA composition differed between layers (albeit differences were small, see above). Results comparing non-lactating and lactating females were inconclusive because underlying assumptions were not sufficiently met. FA composition at the sternum 


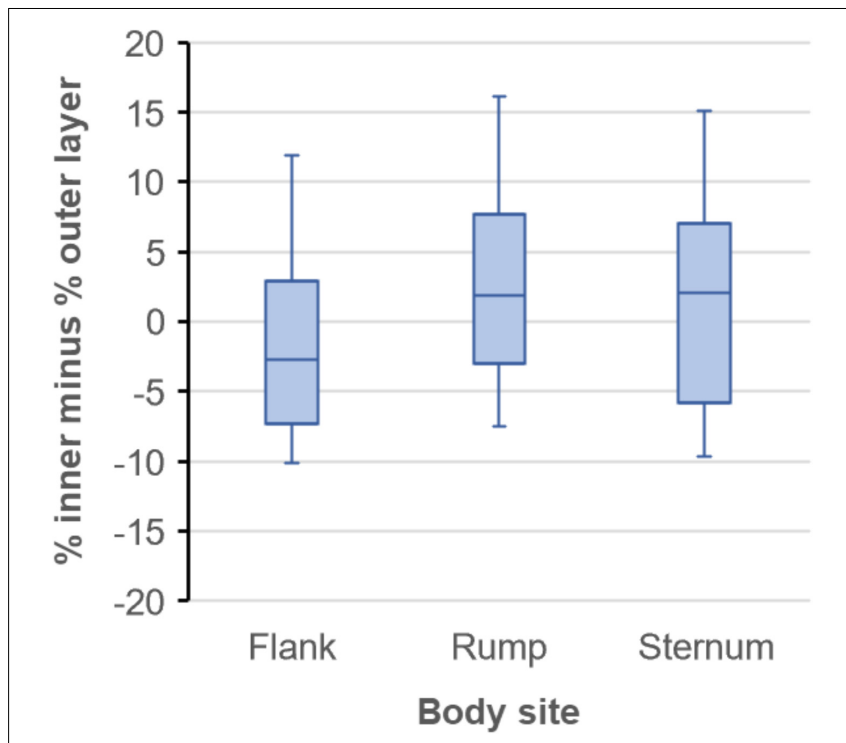

FIGURE 2 | Observed differences in percent lipid content between inner and outer blubber layers among three body sites of 15 lactating Pacific walruses in spring 2007 (plots indicate median, 25th and 75th percentile (box), and minimum and maximum (whiskers).

of lactating females differed among years (Figure 5) (Wilks' $\Lambda=0.006, P<0.0001)$ with some individual FAs differing by up to $6 \%(18: 1 n-9)$ among years (Figure 6). In general, FA composition was highest for 16:1n-7 ( 23\%), near 10\% for $16: 0,18: 1 n-9,18: 1 n-7$, and $20: 5 n-3$, and near or below $5 \%$ for the remaining FAs.

\section{DISCUSSION}

Percent lipid content did not differ between the inner and outer blubber layers at the rump, flank, or sternum of lactating walruses. Although FAs differed between the inner and outer blubber layers, the difference was consistent across body sites (Figure 3), and differences between layers within individual FAs were small $(<2 \%)$ (Figure 4$)$. The inner layer contained slightly higher amounts of saturated FAs and slightly lower amounts of shorter-chained monounsaturated FAs than the outer layer, which is consistent with the directional differences of these FA groups with blubber depth observed in 18 adult male Atlantic walruses (Skoglund et al., 2010). Our study suggests that sampling the outer layer may sufficiently represent percent lipid content of the full blubber depth at any of the three body sites. Although very low to substantial stratification of fatty acids with blubber depth have been shown to occur among pinnipeds (Lambert et al., 2013; Tverin et al., 2019), our study suggests the outer layer may only slightly over- or under-represent the abundance of major FAs of the full blubber depth, which may be of little biological significance (i.e., $<2 \%$ ).

FA composition at the sternum of lactating walruses in our study (Figure 6) is similar to FA levels found in adult female Pacific walruses sampled in 2002 by Budge et al. (2007) during the same season and in a similar region as ours. FA profiles were characterized by high levels of monounsaturated FAs, primarily 16:1n-7, followed by $18: 1 n-9$ and 18:1n-7. Polyunsaturated FAs were dominated by $20: 5 n-3,22: 5 n-3$, and $22: 6 n-3$, and saturated FAs were dominated by 16:0. These patterns were also evident in full-depth FA profiles of Atlantic walruses opportunistically sampled in summer at two locations in the Canadian Arctic (Thiemann et al., 2008).

We were not able to assess variation in lipid content with stage of lactation, but nevertheless, the $6 \%$ higher lipid content we found at the sternum of lactating females compared to non-lactating females suggests blubber lipid content reflects differences in condition among female reproductive classes and is consistent with the greater weight and higher lipid stores that would be expected in lactating females with recently born calves compared to non-lactating females (Noren et al., 2014). In contrast, Quakenbush et al. (1999) did not detect a difference in blubber thickness at the sternum between near-term pregnant and adult non-pregnant females. Similarly, although Noren et al. (2015) found blubber thickness measured dorsomedially at the shoulder was the best predictor of body condition (quantified as mass $\times$ length $^{-1}$ ) among multiple sites in captive nonpregnant walruses, all sites were relatively poor indicators of body condition compared to total blubber mass. Rather, body condition was highly correlated to total blubber mass estimated from three measures of blubber thickness at seven girth sites, data that cannot be collected in most field settings. Thus, percent lipid collected at a single body site may be a more sensitive indicator of total body fat than a measure of blubber thickness.

Interannual variation in blubber lipid content (range 18\%) and individual FAs (range 6\%, Figure 6) at the sternum of the female walruses in our study likely reflected population-level variability in energy budgets and small differences in diet among years. The walruses in our study were harvested by subsistence hunters in spring as the population migrates from its winter range in the Bering Sea to its summering grounds in the Chukchi Sea (Fay, 1982). Sea ice habitat in these seas, particularly in the Chukchi Sea, are undergoing rapid change in seasonal ice extent and thickness due to climate warming. The summer of 2007 marked the start of record-setting low summertime sea ice extents over the Chukchi Sea shelf (Stroeve et al., 2008; Wang and Overland, 2009). This reduction in ice extent caused walruses to begin hauling out in large numbers on the coasts of Alaska and northern Chukotka for extended periods in autumn (Jay et al., 2012) with associated decreased energy efficiencies (Jay et al., 2017). The low 70\% lipid content we observed in sternum samples from lactating females in spring 2009 contrasts sharply with the near- $80 \%$ and higher lipid content in the other three years of our study and the $82 \%$ mean lipid content measured from four adult female walruses (reproductive status unknown) in spring of 1995 and 1996 in a separate study (Kucklick et al., 2006). Although we cannot draw a causal link between these interannual differences in lipid content and changes in seasonal sea ice conditions in the Chukchi Sea, we demonstrated an ability to detect interannual lipid content differences of $8 \%$ with modest sample sizes. 
Jay et al.

Walrus Lipids and Fatty Acids

Flank $\square$ Rump $\square$ Sternum

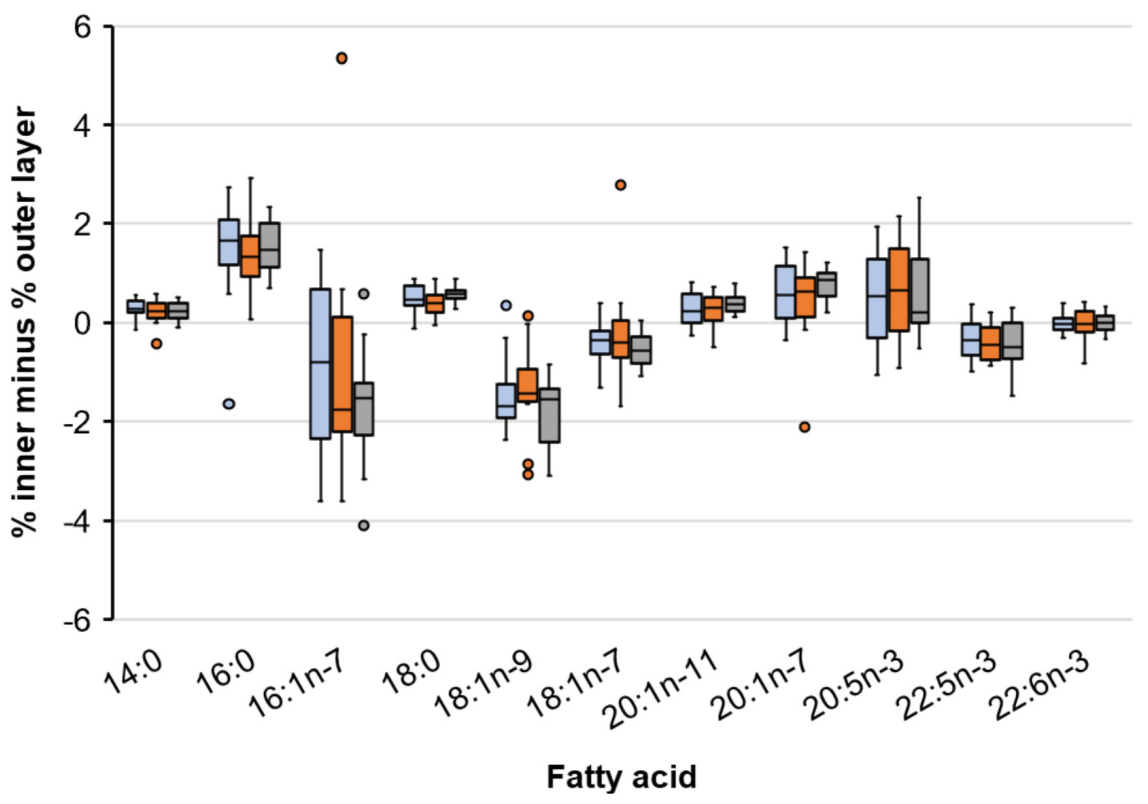

FIGURE 3 | Observed differences in percent abundance of major fatty acids between inner and outer blubber layers among three body sites of 15 lactating Pacific walruses in spring 2007 (plots indicate median, 25th and 75th percentile (box), and minimum and maximum (whiskers) excluding outlier points which are beyond 1.5 times the interquartile range).

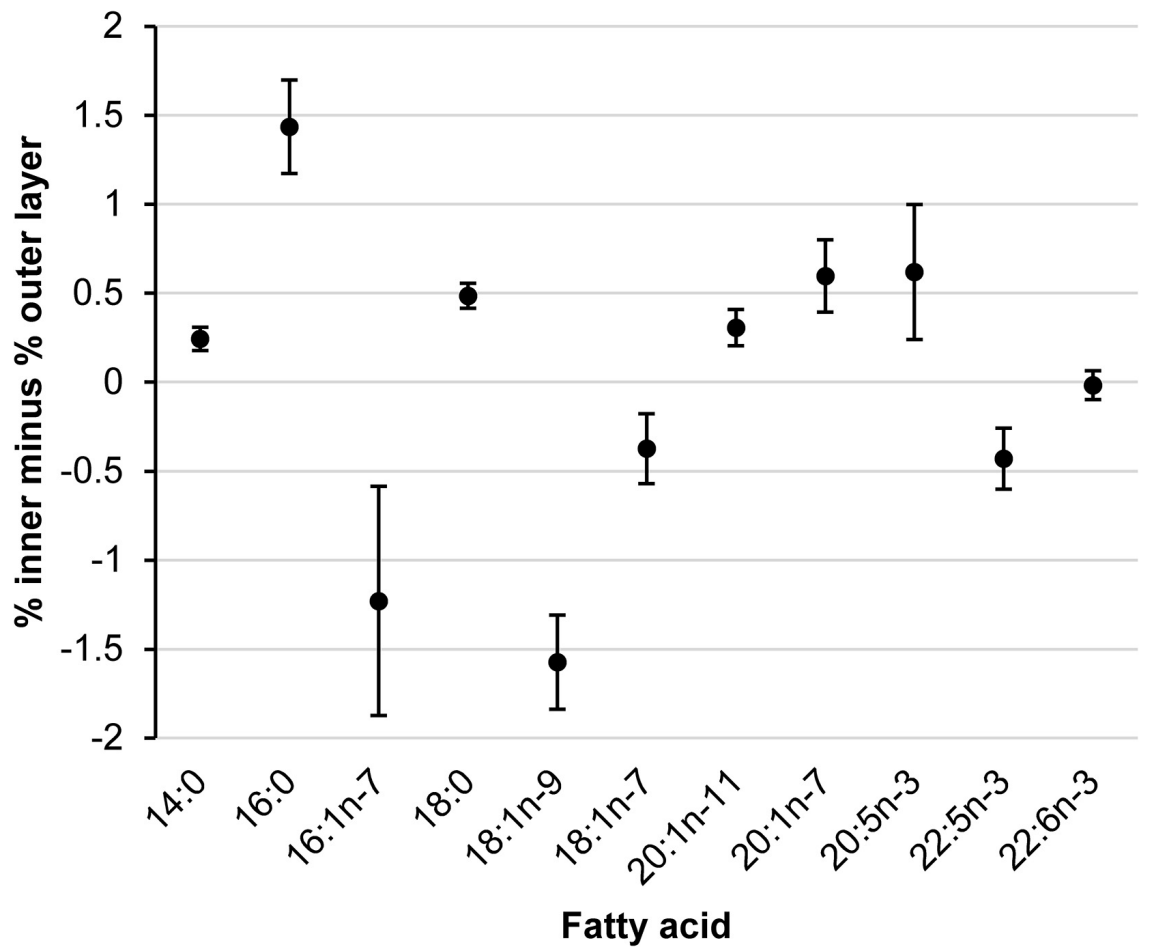

FIGURE 4 | Estimated mean ( \pm 2SE) difference in percent abundance of major fatty acids between inner and outer blubber layers averaged across three body sites within 15 lactating Pacific walruses in spring 2007.

Frontiers in Marine Science | www.frontiersin.org

6

January 2021 | Volume 8 | Article 603065 


\section{$\square 2007 \square 2008 \square 2009 \square 2010$}

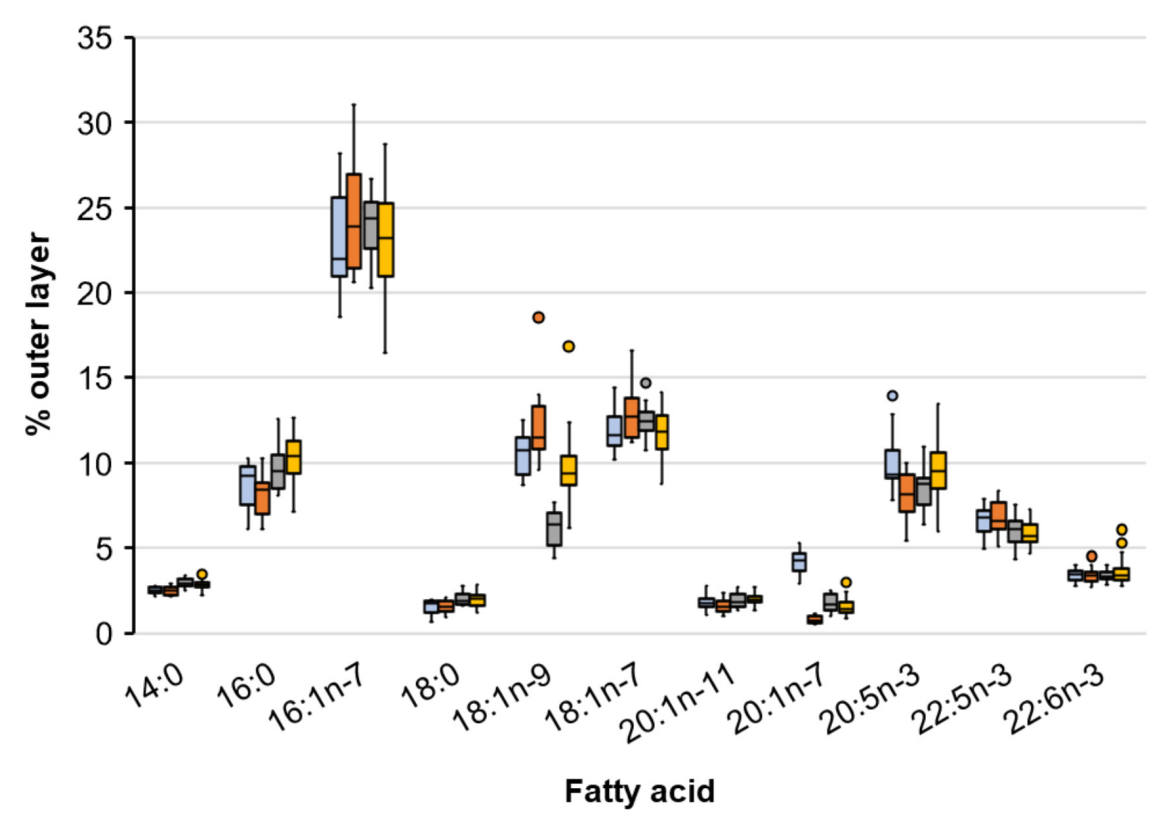

FIGURE 5 | Observed composition in percent abundance of major fatty acids of the outer blubber layer from the sternum of 17,16 , 15, and 52 lactating Pacific walruses in spring 2007-2010, respectively (plots indicate median, 25th and 75th percentile (box), and minimum and maximum (whiskers) excluding outlier points which are beyond 1.5 times the interquartile range).

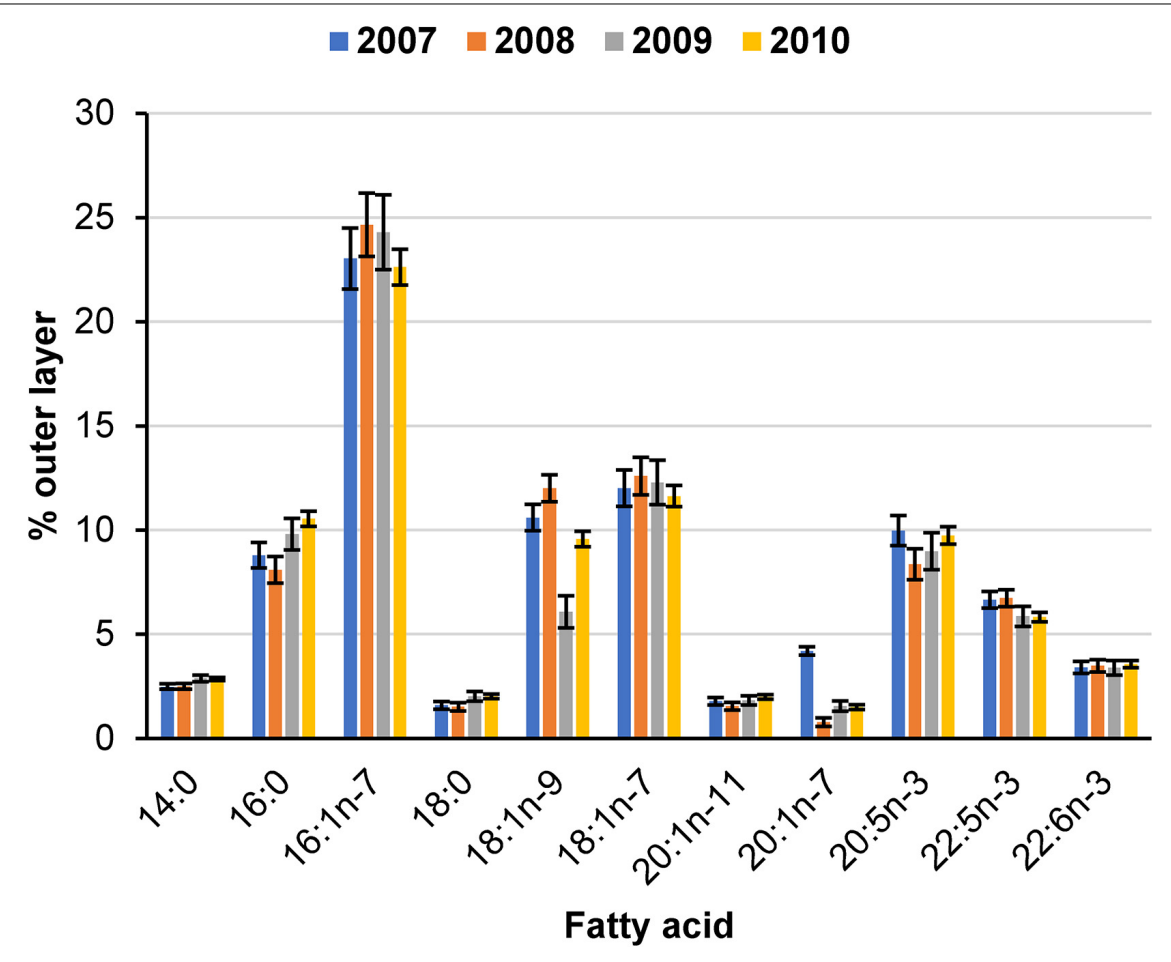

FIGURE 6 | Estimated mean ( \pm 2SE) composition in percent abundance of major fatty acids of the outer blubber layer from the sternum of $17,16,15$, and 52 lactating Pacific walruses in spring 2007-2010, respectively. 
Decline in sea ice conditions are expected to continue through this century (Wang et al., 2018) and concerns of potential future declines in the Pacific walrus population (MacCracken et al., 2017) highlight the need to develop methods of tracking population status and identifying sources and drivers of population change. Investigating body indices that correlate with fat stores may be useful in this endeavor if they can be shown to relate to environmental conditions, human-caused stressors, or population vital rates (Stevenson and Woods, 2006; Booth et al., 2020). Measures of lipid content in walrus blubber samples may be worth further exploration as an index of body condition. The same samples can be analyzed for FAs, including the more unique NMI FAs that are common to all bivalves, a main prey type of walruses (Budge et al., 2007), and potentially provide insights into changes in walrus diet that may be expected to occur from changes in their access to prey resources resulting from continued sea ice loss.

\section{DATA AVAILABILITY STATEMENT}

The datasets analyzed for this study can be found in the U.S. Geological Survey data release, https://doi.org/10.5066/ P9P9GX3E.

\section{ETHICS STATEMENT}

Research and sample collection were conducted in accordance with U.S. Fish and Wildlife Service, Division of Management Authority, permit numbers: MA801652-3 through MA801652-6.

\section{REFERENCES}

American Society of Mammalogists (1967). Standard measurements of seals. J. Mammal. 48, 459-462. doi: 10.2307/1377778

Booth, C. G., Sinclair, R. R., and Harwood, J. (2020). Methods for monitoring for the population consequences of disturbance in marine mammals: a review. Front. Mar. Sci. 7:115. doi: 10.3389/fmars.2020.00115

Bromaghin, J. F., Budge, S. M., Thiemann, G. W., and Rode, K. D. (2017). Simultaneous estimation of diet composition and calibration coefficients with fatty acid signature data. Ecol. Evol. 7, 6103-6113. doi: 10.1002/ece3.31 79

Budge, S. M., Iverson, S. J., and Koopman, H. N. (2006). Studying trophic ecology in marine ecosystems using fatty acids: a primer on analysis and interpretation. Mar. Mam. Sci. 22, 759-801. doi: 10.1111/j.1748-7692.2006.0007 9.x

Budge, S. M., Springer, A. M., Iverson, S. J., and Sheffield, G. (2007). Fatty acid biomarkers reveal niche separation in an Arctic benthic food web. Mar. Ecol. Progr. Ser. 336, 305-309. doi: 10.3354/meps336305

Castrillon, J., Huston, W., and Bengtson Nash, S. (2017). The blubber adipocyte index: a nondestructive biomarker of adiposity in humpback whales (Megaptera novaeangliae). Ecol. Evol. 7, 5131-5139. doi: 10.1002/ece3.2913

Farmer, N. A., Baker, K., Zeddies, D. G., Denes, S. L., Noren, D. P., Garrison, L. P., et al. (2018). Population consequences of disturbance by offshore oil and gas activity for endangered sperm whales (Physeter macrocephalus). Biol. Conserv. 227, 189-204. doi: 10.1016/j.biocon.2018.09.006

Fay, F. H. (1982). Ecology and Biology of the Pacific Walrus, Odobenus Rosmarus Divergens Illiger. Number 74, U.S. Department of the Interior, Fish and Wildlife Service. Washington, DC: North American Fauna.

Fay, F. H. (1985). Odobenus Rosmarus: Mammalian Species No. 238. Topeka, KS: The American Society of Mammalogists.

\section{AUTHOR CONTRIBUTIONS}

CJ, SI, and AF contributed to conception and design of the study and wrote sections of the manuscript. SI organized the database. CJ performed the statistical analysis and wrote the first draft of the manuscript. All authors contributed to manuscript revision, read, and approved the submitted version.

\section{FUNDING}

This research was funded by the U.S. Geological Survey's Changing Arctic Ecosystems initiative and the Wildlife Program of the Ecosystem Mission Area, as well as equipment grants (SI) from the Natural Sciences and Engineering Research Council (NSERC) of Canada. Additional funding for lab analyses was provided by the North Pacific Research Board (NPRB project \#B67).

\section{ACKNOWLEDGMENTS}

We thank Savoonga and Gambell hunters and USFWS biomonitors J. Snyder and B. Benter for blubber sample collections. We also thank the Eskimo Walrus Commission for their interest in supporting this project. Any use of trade, firm, or product names is for descriptive purposes only and does not imply endorsement by the U.S. Government.

Galicia, M. P., Thiemann, G. W., and Dyck, M. G. (2020). Correlates of seasonal change in the body condition of an Arctic top predator. Glob. Chang Biol. 26, $840-850$.

Grebmeier, J. M. (2012). Shifting patterns of life in the pacific arctic and sub-Arctic Seas. Ann. Rev. Mar. Sci. 4, 63-78. doi: 10.1146/annurev-marine-120710100926

Grebmeier, J. M., Bluhm, B. A., Cooper, L. W., Danielson, S. L., Arrigo, K. R., Blanchard, A. L., et al. (2015). Ecosystem characteristics and processes facilitating persistent macrobenthic biomass hotspots and associated benthivory in the Pacific Arctic. Progr. Oceanogr. 136, 92-114. doi: 10.1016/j. pocean.2015.05.006

Iverson, S. J., Field, C., Don Bowen, W., and Blanchard, W. (2004). Quantitative fatty acid signature analysis: a new method of estimating predator diets. Ecol Monog. 74, 211-235. doi: 10.1890/02-4105

Iverson, S. J., Frost, K. J., and Lang, S. L. (2002). Fat content and fatty acid composition of forage fish and invertebrates in Prince William Sound, Alaska: factors contributing to among and within species variability. Mar. Ecol. Progr. Ser. 241, 161-181. doi: 10.3354/meps 241161

Iverson, S. J., Lang, S. L., and Cooper, M. H. (2001). Comparison of the Bligh and Dyer and Folch methods for total lipid determination in a broad range of marine tissue. Lipids 36, 1283-1287. doi: 10.1007/s11745-001-0843-0

Jay, C. V., Fischbach, A. S., and Kochnev, A. A. (2012). Walrus areas of use in the Chukchi Sea during sparse sea ice cover. Mar. Ecol. Progr. Ser. 468, 1-13. doi: 10.3354/meps10057

Jay, C. V., Taylor, R. L., Fischbach, A. S., Udevitz, M. S., and Beatty, W. S. (2017). Walrus haul-out and in water activity levels relative to sea ice availability in the Chukchi Sea. J. Mammal. 98, 386-396. doi: 10.1093/jmammal/gyw195

King, S. L., Schick, R. S., Donovan, C., Booth, C. G., Burgman, M., Thomas, L., et al. (2015). An interim framework for assessing the population consequences of disturbance. Methods Ecol. Evol. 6, 1150-1158. doi: 10.1111/2041-210X.12411 
Knutsen, L. O., and Born, E. W. (1994). Body growth in Atlantic walruses (Odobenus rosmarus rosmarus) from Greenland. J. Zool. 234, 371-385. doi: 10.1111/j.1469-7998.1994.tb04854.x

Koopman, H. N., Pabst, D. A., Mclellan, W. A., Dillaman, R., and Read, A. (2002). Changes in blubber distribution and morphology associated with starvation in the harbor porpoise (Phocoena phocoena): evidence for regional differences in blubber structure and function. Physiol. Biochem. Zool. 75, 498-512. doi: $10.1086 / 342799$

Kucklick, J. R., Krahn, M. M., Becker, P. R., Porter, B. J., Schantz, M. M., York, G. S., et al. (2006). Persistent organic pollutants in Alaskan ringed seal (Phoca hispida) and walrus (Odobenus rosmarus) blubber. J. Environ. Monitor. 8, 848-854. doi: $10.1039 / \mathrm{b} 602379 \mathrm{~g}$

Laidre, K. L., Stern, H., Kovacs, K. M., Lowry, L., Moore, S. E., Regehr, E. V., et al. (2015). Arctic marine mammal population status, sea ice habitat loss, and conservation recommendations for the 21st century. Conserv. Biol. 29, 724-737. doi: $10.1111 /$ cobi. 12474

Lambert, A., Meynier, L., Donaldson, L. C., Roe, W. D., and Morel, P. C. H. (2013). Body regional distribution and stratification of fatty acids in the blubber of New Zealand sea lions: implications for diet predictions. J. Comparat. Physiol. B 183, 145-156. doi: 10.1007/s00360-012-0693-4

Louis, C., Dirtu, A. C., Stas, M., Guiot, Y., Malarvannan, G., Das, K., et al. (2014). Mobilisation of lipophilic pollutants from blubber in northern elephant seal pups (Mirounga angustirostris) during the post-weaning fast. Environ. Res. 132, 438-448. doi: 10.1016/j.envres.2014.04.016

MacCracken, J. G., Beatty, W. S., Garlich-Miller, J. L., Kissling, M. L., and Snyder, J. A. (2017). Final Species Status Assessment for the Pacific Walrus (Odobenus rosmarus divergens), May 2017 (Version 1.0). Anchorage, AK: US Fish \& Wildlife Service.

National Research Council (2005). Marine Mammal Populations and Ocean Noise: Determining When Noise Causes Biologically Significant Effects. Washington, DC: The National Academies Press.

New, L., Clark, J., Costa, D., Fleishman, E., Hindell, M., Klanjšček, T., et al. (2014). Using short-term measures of behaviour to estimate long-term fitness of southern elephant seals. Mar. Ecol. Progr. Seri. 496, 99-108. doi: 10.3354/ meps 10547

Noren, S. R., Udevitz, M. S., and Jay, C. V. (2014). Energy demands for maintenance, growth, pregnancy, and lactation of female Pacific walruses (Odobenus rosmarus divergens). Physiol. Biochem. Zool. 87, 837-854. doi: 10. $1086 / 678237$

Noren, S. R., Udevitz, M. S., Triggs, L., Paschke, J., Oland, L., and Jay, C. V. (2015). Identifying a reliable blubber measurement site to assess body condition in a marine mammal with topographically variable blubber, the Pacific walrus. Mar. Mam. Sci. 31, 658-676. doi: 10.1111/mms.12186

North, C. A., Lovvorn, J. R., Kolts, J. M., Brooks, M. L., Cooper, L. W., and Grebmeier, J. M. (2014). Deposit-feeder diets in the Bering Sea: potential effects of climatic loss of sea ice-related microalgal blooms. Ecol. Appl. 24, 1525-1542. doi: 10.1890/13-0486.1

Quakenbush, L., Taras, B., and Kelly, B.P. (1999). Topographic variation in blubber thickness of Pacific walruses, Odobenus rosmarus. Contracted by USGS Alaska Science Center, UAF contract number 97-058R. University of Alaska, School of Fisheries and Ocean Sciences, Fairbanks. 25, https://www.arlis.org/docs/vol1/P/ 1164156463.pdf.

Ryg, M., Lydersen, C., Markussen, N. H., Smith, T. G., and Øritsland, N. A. (1990). Estimating the blubber content of phocid seals. Canad. J. Fish. Aquat. Sci. 47, 1223-1227. doi: 10.1139/f90- 142
Schemmel, R. (1976). Physiological considerations of lipid storage and utilization. Am. Zool. 16, 661-670. doi: 10.1093/icb/16.4.661

Schollmeier, T., Oliveira, A. C. M., Wooller, M. J., and Iken, K. (2017). Tracing sea ice algae into various benthic feeding types on the Chukchi Sea shelf. Polar Biol. 41, 207-224. doi: 10.1007/s00300-017-2182-4

Sheffield, G., and Grebmeier, J. M. (2009). Pacific walrus (Odobenus rosmarus divergens): differential prey digestion and diet. Mar. Mamm. Sci. 25, 761-777. doi: 10.1111/j.1748-7692.2009.00316.x

Skoglund, E. G., Lydersen, C., Grahl-Nielsen, O., Haug, T., and Kovacs, K. M. (2010). Fatty acid composition of the blubber and dermis of adult male Atlantic walruses (Odobenus rosmarus rosmarus) in Svalbard, and their potential prey. Mar. Biol. Res. 6, 239-250. doi: 10.1080/17451000903233755

Sonsthagen, S. A., Jay, C. V., Cornman, R. S., Fischbach, A. S., Grebmeier, J. M., and Talbot, S. L. (2020). DNA metabarcoding of feces to infer summer diet of Pacific walruses. Mar. Mamm. Sci. 36, 1196-1211. doi: 10.1111/mms.12717

Stevenson, R. D., and Woods, W. A. Jr. (2006). Condition indices for conservation: new uses for evolving tools. Integr. Comp. Biol. 46, 1169-1190. doi: 10.1093/ $\mathrm{icb} / \mathrm{icl} 052$

Stroeve, J., Serreze, M., Drobot, S., Gearheard, S., Holland, M., Maslanik, J., et al. (2008). Arctic sea ice extent plummets in 2007. EOS 89, 13-20. doi: 10.1029/ 2008eo020001

Thiemann, G. W., Iverson, S. J., and Stirling, I. (2008). Variation in blubber fatty acid composition among marine mammals in the Canadian Arctic. Mar. Mamm. Sci. 24, 91-111. doi: 10.1111/j.1748-7692.2007.00165.x

Tverin, M., Westberg, M., Kokkonen, I., Tang, P., Lehmann, P., Lundström, K., et al. (2019). Factors affecting the degree of vertical stratification of fatty acids in grey seal blubber. Mar. Biol. 166:105.

Udevitz, M. S., Jay, C. V., Taylor, R. L., Fischbach, A. S., Beatty, W. S., and Noren, S. R. (2017). Forecasting consequences of changing sea ice availability for Pacific walruses. Ecosphere 8:e02014. doi: 10.1002/ecs2.2014

Wang, M., and Overland, J. E. (2009). A sea ice free summer Arctic within 30 years? Geophys. Res. Lett. 36:L07502.

Wang, M., Yang, Q., Overland, J. E., and Stabeno, P. (2018). Sea-ice cover timing in the Pacific Arctic: the present and projections to mid-century by selected CMIP5 models. Deep Sea Res. Pt. II 152, 22-34. doi: 10.1016/j.dsr2.2017.11.017

West, G. C., Burns, J. J., and Modafferi, M. (1979). Fatty acid composition of Pacific walrus skin and blubber fats. Canad. J. Zool. 57, 1249-1255. doi: 10.1139/z79161

Wilder, S. M., Raubenheimer, D., Simpson, S. J., and Lee, K. P. (2016). Moving beyond body condition indices as an estimate of fitness in ecological and evolutionary studies. Funct. Ecol. 30, 108-115. doi: 10.1111/1365-2435.12460

Young, R. A. (1976). Fat, energy and mammalian survival. Am. Zool. 16, 699-710. doi: $10.1093 / \mathrm{icb} / 16.4 .699$

Zar, J. H. (1999). Biostatistical Analysis. Upper Saddle River, NJ: Prentice-Hall, Inc.

Conflict of Interest: The authors declare that the research was conducted in the absence of any commercial or financial relationships that could be construed as a potential conflict of interest.

Copyright (C) 2021 Jay, Iverson and Fischbach. This is an open-access article distributed under the terms of the Creative Commons Attribution License (CC BY). The use, distribution or reproduction in other forums is permitted, provided the original author(s) and the copyright owner(s) are credited and that the original publication in this journal is cited, in accordance with accepted academic practice. No use, distribution or reproduction is permitted which does not comply with these terms. 